\title{
Use of Popular Culture Texts in Mother Tongue Education
}

\author{
Mazhar BAL ${ }^{1}$ \\ ${ }^{1}$ Turkish Language Education Department, Akdeniz University, Antalya, Turkey \\ Correspondence: Mazhar BAL, Turkish Language Education Department, Akdeniz University, Antalya, Turkey, \\ Tel: 9-543-311-0004. E-mail: balmazhar@gmail.com
}

\begin{tabular}{|c|c|c|}
\hline 2018 & Accepted: March 10, 2018 & Online Published: March 20, 2018 \\
\hline $5539 /$ iel y $7 \mathrm{n} 2$ & URL $\cdot$ httnc $/ /$ doi oro $/ 105$ & $\operatorname{lv} 7 \mathrm{n} 2 \mathrm{n} 293$ \\
\hline
\end{tabular}

This study was prepared by using some of the data of the doctoral thesis titled "Use of Popular Culture Texts in Mother Tongue Education" in Çanakkale Onsekiz Mart University Educational Sciences Institute Turkish Language Education Department.

\begin{abstract}
The aim of this study was to associate popular culture texts with Turkish language lessons of middle school students. For this purpose, a model was proposed and a suitable curriculum was prepared for this model. It was aimed to determine how this program, which was the result of associating popular culture texts with Turkish language lesson outcomes, operated during classroom practices. The study was designed based on action research principles. The participants of the research were 19 (12 males and 7 females) seventh grade students. These pariticipants were selected according to the criterion sampling technique. Audio and video recording, questionnaire form, student and research diary, observation form, student activity files were used as data collection tools. Descriptive analysis technique was used in the analysis of these data. According to research data, it was seen that the Turkish language lessons associated with popular culture texts contributed to the development of basic language skills and developed a critical perspective on popular culture texts. However, for the action research process, students expressed their opinion that the lessons were fun and related to out of school life.
\end{abstract}

Keywords: mother tongue education, language arts, popular culture, hip hop, comic books, cartoons

\section{Introduction}

It is known that the media is increasingly taking its place in human life, further enhancing the influence of popular cultures. It is thought that the popular concept should be clarified before describing what is popular culture. The popular concept that has come from etymologically folk words (Yaylagül \& Korkmaz, 2008) defines "in the sense of being loved and chosen by the majority" (Erdoğan \& Alemdar, 2005, p. 33). Although it is known that it appeals to a large majority, it is noteworthy that there is uncertainty about popular culture (Browne, 2006) and studies of contradiction (Petracca \& Sorapure, 1998). One can say that popular culture is an inseparable part of the society in which the individual is living, based on the statements made about the popular culture (Childs, 2014; Chua, 2012, Otmazgin \& Project, 2014).

Popular culture is costly to the public, appealing to the public, closely related to tradition and accessible to the public. Because of the fact that it is so publicly oriented, it is both influenced by the way people live and affect their way of life (Petracca \& Sorapure, 1998). One of the important elements of people's life is education. It is known that education and curriculum are important for the success of education. The individual must be willing to participate in these processes (Demirel, 2010) as the programs are based on the individual's experience and should include all the in-school and out-of-school experiences of the individual (Ornstein \& Hunkins, 2014). Turkish Language Curriculum is centered in and out of school experiences (Ucgun, 2014). Although the educational system in Turkey is based on this perspective, its achievability is still debated today because teachers try to maintain learning-centered perspective with the activities that teachers have prepared before coming to class (Oktay, 2010). On the other hand, the educational goal should not be kept away from the experiences of everyday life (McLaren, 2011). In this respect, the adequacy of Turkish Language Curriculum is discussed. The results of the PISA (2012) on the topic of in and out of school unification are very important. According to PISA (2012) results; students in Turkey have been excluded from their schools and felt that they did not belong to their 
schools. One of the reasons for this is to achieve the aim of raising the ideal human type with the aims and outcomes of the educational program.

On the contrary, it is a popular culture with a pluralistic view that is different in education (Güngör, 1999). Therefore, it should not be confined to certain limitations in order not to adversely affect the language education (Chomsky, 2007). It is thought that students should integrate emotionally considering of all differences. Nevertheless, an educator should know first and foremost how to benefit from the physical and social environment in the educational process (Dewey, 1966). This suggests the importance of the concept of "popular culture", which is accepted by a certain majority and which affects people's lives, influenced by the social circle which is an indispensable part of education, and by the influence of culture, especially mass culture (Erdoğan, 1999). Because popular culture fills the gap between the official program of a particular curriculum and the out-of-school experience of children (Alvermann, 2012). This view seems to be rather difficult for some people, but it is thought that it will be very easy to adapt to popular cultural class activities, especially in language education. In addition, the integration of popular cultures with Turkish language lessons might make it not possible for children to feel as if they are strangers to school, or that something is missing in school (PISA, 2012). Today, Australia (http://www.achistoryunits.edu.au), Canada (http://www.edu.gov.on.ca/eng/), USA (http://www.corestandards.org), Hong Countries such as Kong (Benson \& Patkin, 2013; Koh, 2015) and Finland (http://www.minedu.fi/OPM/?lang=en) place popular culture texts that make up the daily lives of students in their language education. But the mother tongue education in Turkey has been separated from daily life in that texts used in mother tongue classrooms do not awaken students's interest (Epçaçan \& Erzen, 2008; Day, 1999), reading habits can not be acquired due to selected texts and activities (Durukan, 2008), the level of students in the choice of text was not observed (Karabay, 2014), and the activities did not address the everyday life of the students (Sever, 2011). The reasons resulting in these situations are generally related to not observing student diversity and that students' daily lives and Turkish language lessons can not be combined. In this respect, this study on a Turkish lesson associated with popular culture is considered important because it will have a positive effect on student attitudes. As a result of the analysis of related literature in popular culture studies in Turkey, said that living in a systematic manner. This does not mean that there is no work on popular culture. Studies about popular culture in Turkey are available; but it is usually done in the field of communication studies. Particularly, it can be said that working in the mother tongue education will contribute to the field when considering the shortage in the field.

\section{Method}

\subsection{Research Design}

In this research, a model was developed for associating 7th grade students with popular culture texts of Turkish language course. To reveal the effectiveness of this model, action research design was used. Although studies have been carried out in different aims and areas, action research is generally used in education (Cammarota, Romero, \& Stovall, 2014). Particularly, it is accepted as a teacher research with a solution proposal for classroom problems (Pelton, 2010; Zeichner, 2009). In this study, it was thought that it would be appropriate to design the schools as a better place for children and what to do about it (Calhoun, 1994).

\subsection{Research Group}

The study group was selected by criteria sampling technique. Criterias were determined by the researcher according to the purpose of the research (Yıldirım \& Simsek, 2013). It has been determined that the parents, the teachers and the school management are willing to participate in the work. In addition, Turkish teachers are among the criteria to be observer during the application process. Participants of the selected study in accordance with the determined criteria constitute 7th grade students in a class consisting of 19 (12 male, 7 female) students.

\subsection{Data Collection Techniques}

In the action research, it is important to determine which data collection tools will be used after the problem situation is identified (Ferranca, 2000). Therefore, more than one data collection tool were used to ensure the validity and reliability of this study (Johnson, 2014; Yildirim \& Simsek, 2013). In this study, video recording, student diary, observation form, research diary and student activity files were used as data collection tools.

\subsubsection{Video Recording}

The video recordings are used to reveal nonverbal behaviors of students (Johnson, 2014) and to capture unrecognized details (Mills, 2003). Although they provide important opportunities for the researcher, video recordings may be perceived as an anxiety provoking factor regarding the participants (Johnson, 2014). In order to reduce this anxiety, the researcher recorded 10 lessons to observe the participants' reactions (during 2 weeks) 
prior to the actual research. It was noted that students were not bothered by the existence of the video recording. In addition, an average of 1,160 minutes of video recording was obtained during the 29 hours action research process.

\subsubsection{Student Diary}

19 students were asked to keep diaries at the end of the each course. In the diaries, the participants were required to answer 7 questions regarding the evaluation of learning, teaching process, and student view.Thanks to these diaries, the students were informed about their personal observations, comments and reactions about the lesson (Yildirım \& Simsek, 2013). In this voluntary data collection process 96 diaries were collected during 6 weeks.

\subsubsection{Semi-structured Observation Form}

Semi-structured observation was developed in accordance with the dimensions of the research to be observed since it is difficult for the researcher to be both practitioner and observer in the process of action research (Yildirim \& Simsek, 2013). The questions in the semi-structured observation form were created according to the aims of the research. The developed questions were presented to the approval of 7 instructors in order to determine whether the dimensions of observation, physical environment, social dimension of the environment, observation questions about the activities were suitable for observation form to draw attention to the communication language in the environment (Ylldirım \& Simsek, 2013). After the expert opinions were received, a pilot application was made to see if the observation form was appropriate for clarity. The observation form with the feedback from the pilot application made by the three Turkish language teachers was given last. There were six questions in the semi-structured observation form. Questions were generally followed a correct sequence specific for the purposes of the research. Observations were made by the Turkish language teacher Müge. Patton (2014, pp. 259-335) on "Qualitative Research and Evaluation Methods" related to the observation technique was provided to the Müge teacher prior to the research process for this and the information about the observation technique was provided. At the end of the 6 week research process, 4 weeks observation could not be made because the teacher could not come due to the special circumstances. A total of 14 observation forms were collected in the process.

\subsubsection{Research Diary}

The researcher had detailed opinions and observations on the whole process (Johnson, 2014). During the action research process, researcher kept a diary based on concrete examples on daily basis, which would be valid (Yildirim \& Simsek, 2013). These descriptive diaries, written at the end of each day in the research process contributed to the analysis of the data.

\subsubsection{Student Activity Files}

The workbook was given to students in the form of work sheets in accordance with the plan. A total of 28 work sheets were distributed to each student. These work sheets were used in the analysis process in response to research questions (Yildirim \& Simsek, 2013). In the analysis process, the work sheets (168 work sheets) of the 6 students who were the key participants were used.

\subsection{Data Collection Process}

The three steps before the research data collection process and the prepared plan (implementation of the instructional package) (identifying and defining the focus of the action, the theoretical basis of the action plan and the need analysis of the teaching process, making the content) will be introduced.

\subsubsection{First Stage}

Determining the focus point: In order to be able to present the problem situation to the scientist by the researcher, interviews were first made with the teacher and then with the family and the latest students (see Bal, 2016). Based on the views of teachers and parents, it was based on the outcomes related to popular culture skill field. As a direct observer in this regard, the interests of the students constituting the out-of-school life and the attitudes of both the parents and the teachers and the students regarding these interests were presented. Thus, a framework was established on how to relate popular culture texts to Turkish language lessons and which needed to be answered. The next stage was a search of the popular culture. Firstly, the programs of the countries were screened in terms of popular cultural outcomes. Work on popular culture by the Australian Ministry of Education (http://www.australia.gov.au), popular culture-related outcomes (http://www.achistoryunits.edu.au); popular cultural outcomes in the Toronto State's curriculum for grades 1-8 in Canada (http://www.edu.gov.on.ca/eng/); it is applied in America 6-8. the acquisition of language curriculum (http://www.corestandards.org); Learning English with Popular Culture, which one of the elective courses in the "New Senior Secondary" program in 
Hong Kong (Benson \& Patkin, 2013; Koh, 2015) were investigated. It was also available in Ireland (http://www.education.ie/en/), Spain (http://www.mecd.gob.es/portada-mecd/en/), $\quad$ Sweden (http://www.government.se/), Korea (http://english.moe.go.kr/enMain.do), Hungary (http://www.nefmi.gov.hu/english) mother tongue curriculum were analyzed by content analysis. Along with these, local and foreign studies on popular were included in the analysis. As a result of content analysis and expert opinions, 9 goals, 53 outcomes were achieved (see Bal, 2016).

\subsubsection{Second Stage}

The theoretical basis of the action plan and the needed analysis of the teaching process: It was suggested that the basic features of the action research may be related to a theory. Associating the work with a particular theory or theory provides regularity and facilitates comprehension (Johnson, 2005; Schoen \& Nolen, 2004). For this reason, Transactions (Transactional) and Reader Response Teories were used while the action plan of the researcher was prepared and the course contents were being edited. The reason for using this theory was that it conforms to the nature of the constructivist approach on which the Turkish Language Curriculum is based. However, constructivist approach is an educational approach to all disciplines, Transactions (Transactional) and Reader Response Teories are based on the skills of narrative and comprehension, which are the basic skills of Turkish Language Curriculum.

Reader-Response Theory (Rosenbaltt, 1982) and Transactional Theory (Rosenblatt, 1988) from a lesson plan for teaching-learning process was used to create the action plan. These five digits, which follow a hierarchical order towards high-level thinking skills, are: "Preliminary information, Interaction, Perspective, Interpretation, and Reconstruction". The steps of the action plan were set up to determine the content of the course after the steps to be taken according to the Literate-Response and Transactional Theory have been established. At this stage, a questionnaire consisting of 28 questions was administered to the students aiming to determine popular culture texts that constitute the out of school life of the students (see Bal, 2016).

\subsubsection{Third Stage}

Creating of content: the final step in the action plan came to an end after the focus were identified, the outcomes made, the action plan based on an establishment, and the need analysis of the interests of the students. Content was created at this stage. Even if all the data were used at this stage of the research while the content was being created, the basic point is Primary Education 6-8. Classroom Turkish Language Curriculum (2006) has been. As a result of the review, it was decided that the content should be prepared in terms of love theme which was the first theme. Within the theme of Love, there are four main texts under four sub-themes. In accordance with these sub-themes, prior to designing the content, the needs analysis of the popular culture texts, which were the interests of the students, is looked at as a result and it is considered which texts can be used as course content. From the responses of the students to the questionnaire, 5 listening-watching and 5 reading texts were chosen. These selected texts met the theme of Love; but it is thought that the texts are better suited to the sub-themes "Human Love, Homeland Love, Family Love, Nation Love" under the theme of Love in the Turkish Langiage Curriculum (2006), since the sub topics can not be met in the same order. In this case, while the content is being created, the rap song of the Sevgi İsleyin of singer Ceza for the sub-theme of Human Love, for the sub-theme of Motherland Love, a superhero comic book called Justice League; for the sub-theme of Family Love, Spongebob: Cartoon called Grandmamma Kiss; for Nation Love sub-theme, footballer cards were chosen. After sub-themes and texts have been selected, the activity has been developed in accordance with the outcomes. While the activities were being developed, the teaching steps described in the previous section and based on the theory of Rosenblatt were taken into account. Each sub-theme consists of the steps of "preliminary information, interaction, perspective, interpretation, reconstruction". There are two suitable activities for the purpose of teaching steps in each step. These activities were prepared according to the aims and outcomes of the Turkish language lesson in the Elementary Turkish Language 7th Grade Teacher's Guidebook (2015, pp. 68-77) and on the popular culture acquisitions appropriate for the outcomes. After the activities were created, they were arranged in three different booklets. The first booklet is the student workbook in which the activities take place; the second booklet, the booklet containing the texts of the lesson; and the third is the teacher's guidebook showing the lesson plans and what effect they serve (see Bal, 2016). The research process of the study lasted 6 weeks. During this period of 6 weeks, the researcher entered Turkish language lesson 5 times a week both as researcher and practitioner. During the research process, the school's curriculum has changed three times. But the only thing that has changed is the days of lessons. The distribution of lesson hours has not changed. According to this, three lessons a week were to be Turkish language lessons of the study group. The study was conducted in 29 hours. 


\subsection{Analysis of Data}

For the analysis of the data, course content was determined. The teaching process of this course was applied according to the five instructional steps developed from the Theory of Reader Response and Transactional Theory. These five steps were accepted as the theme (Yıldırım \& Simsek, 2013) and the analysis process has was carried out as a descriptive analysis. During the research process, the application lessons were analyzed by macro analysis the video recording, student diary, observations, research diary, research purposes. From the research questions, macro analyzes were carried out in three different ways. Macro analyzes of the third research question, whose codes were generated using descriptive analysis, were presented to the validity committee every week. Before the analysis results were submitted to the validity committee, the table was revised. In the analysis, information about the course, date, who received it, minutes and seconds were given. These analyses were discussed at weekly meetings of the validity committee. At the end of the research process, all collected data were analyzed by micro analysis technique. For this purpose, the data were loaded into the qualitative data analysis program and transferred to the separate files without any modification. After the data transfer process, a field specialist confirmed the consistency of the transmitted data. Macro analysis with the approval of the validity committee in the process and analysis of the post implementation data are combined and coded by another field expert. After coding, both codes were compared; disagreements were discussed and some changes were made. The consistency between the coding and the coding reliability was found to be $85 \%$ (Miles \& Huberman, 1994, p. 64).

\subsection{Validity and Reliability}

Generalizability is not involved in the action research; it is used to investigate more specific cases and to transfer the results found to similar situations (Johnson, 2014). Therefore, it is not possible to directly apply actions on internal validity, objectivity, reliability, external validity to action researches (Kuzu, 2009). Instead, procedures for credibility, transferability, trustworthiness, and appro- priity (Guba, 1981 as cited in Uzuner, 2005) were used to determine the validity of the research.

\subsubsection{Credibility}

To ensure the credibility, the research process took a total of 8 weeks.. Prior to that, as of 22.05 .2015 , researcher vsited the practice school. The researcher participated in the lessons of the 7th grade students and made them know the researcher. In addition, the teacher made detailed observations during the research process, the researcher kepts the research diary, and the lessons were recorded by video camera.

\subsubsection{Transferability}

The researcher reported each step in detail from the beginning of the process. In doing so, another researcher noted that the information in this study was so detailed and clear that it can do the same work again.

\subsubsection{Trustworthiness}

9 different data collection tools were used to ensure the trustworthiness of the research. Detailed explanations were made about the development stage and validity-reliability of these tools.

\subsubsection{Confirmability}

Action research from each different data sources used in the process, were reported in relation to each other. Direct citations were used to relate these correlations.

In addition, a validity committee was established for the research process. The functioning of the action research process, the problems encountered in the process, the analyses made on the process were presented to the validity committee for approval. The cycle of action research was carried out in line with the proposals. Data collected during the research process were included in the study without any changes.

\section{Results}

In this part of the study, data for the six-week research process was presented and interpreted. The data were based on the "preliminary information, interaction, viewpoint, interpretation and reconstruction" steps that are created by the Reader-Response and Transactional Theory, which is the basis of the thesis. Six week research process was carried out according to the theme of Love. Contents are presented according to three sub-themes (Human Love, Homeland Love, Family Love).

\subsection{Human Love}

The research process related to this sub-theme is shown as 8 lesson hours in the Turkish Language Curriculum (2006) annual plan; but it took 9 lessons because it was the first course of the research process, the linkage of 
technology to the course, and the implementation of the research activities associated with technology. The aims and outcomes of the Turkish language course are taken directly in the annual plan. A total of 8 activities related to this sub-theme were realized. Sub-theme of Human Love was associated with hip-hop culture and especially rap music. Preliminary information, interaction, perspective, interpretation, reconstruction steps are as follows:

\subsubsection{Preliminary Information}

Students had two activities at this stage. The first activity was the "Hip Hop Culture" activity. In this activity, students were asked what they knew about hip hop culture. Their schemes about hip hop were determined. Students have been involved in the definition of "a song genre" about hip hop culture. When asked what was the factor that led to the spread of hip hop cultures, the following answers were received:

"Because people are influenced by each other and transferred to others" (Mehmet, research process video, 04.11.2015, 08: 23-08: 26).

"Being fun and sharing on the internet." (Tülay, research process video, 04.11.2015, 08: 02-08: 07).

Then, the activity "Rap Music" was presented. Students were required to specify the differences especially regarding rap music, rock and pop and other music types. Student comments about the activity are as follows:

"Rap music is said to be faster than other types. If such a feeling and general rebellion is generally getting meaningful words." (Emine, the activity file, p. 1).

"It's a fast kind of music. It is said fast and it is fun." (Çağrı, activity file, p. 1).

Referring to comments about rap music, it is noteworthy that they focus on the word and meaning.

\subsubsection{Interaction}

At this stage, the video of the song "Sevgi İşleyin" was given with the text. Then four questions were asked to the students before they listened to the text. In the first question, they did not listen to the song before; they were asked what they listened to. Tülay and Mehmet stated that they listenec rap music when they felt emotionally nervous or when they needed to relax. Demir said that he listened to rap music to discover it; Emine said she listened because she found the words meaningful. Secondly, this song brought to the classroom environment was asked for what purpose. Tülay, Cagrı and Demir stated that they were for having fun without considering the purpose of learning. Unlike Tülay, Demir, Cagrı; Emine and Mehmet stated why this song for information is brought to the class. Later, students were asked about their views on the script from the title and the singer. As for the text, they said:

"There can be a song that speaks to the problem of communication among people." (Emine, activity file, p. 2).

"The song we listen to, I think, we must treat each other with respect." (Cagrı, activity file, p. 2).

In the fourth question, students were asked whether their thoughts changed after listening to the text. Tülay, Ayşenur, Emine and Demir stated that due to individual differences, interpretations about the text could also be different, Çağrı and Mehmet said:

"I think it will be because everyone knows that rap." (Cagr1, activity file, p. 2).

"I do not think everyone's thought is different. Everyone does not like it because everyone has their own nonverbal music." (Mehmet, event file, p. 2).

\subsubsection{Perspective}

At this stage, students listened to rap music called Sevgi İsleyin, which belonged to singer Ceza After the song was played, the word "extortion, handicap, slope, ingenuity" selected from the text. Students were asked to guess the meaning of these words from the context of the text. The students made guesses about the meanings of the words through the text. Some words gave information about the use of a meaning other than the real meaning of an interest or analogy, and it was understood that these uses are called "metaphor". Then, it was written on the board that "a cheap series, a long way, flows into tears, processes love". In these expressions, it was desired to use the words "cheap, long, flowing, working" in both real and metaphoric sentences. After the sample sentences taken from the students, sample sentences including the words "emerging, growing, walking" in the text were written on the board. From students; it was desirable to define the concepts of "work", "being" and "movement" by moving from the example sentences written on the sceen. "Work" for actions that affect students, another entity; "being" of the acts that took place spontaneously; it was said that the person who made the action informs about the actions that were affected by the action he made and informs them with the help of the sample actions. Students were asked to write the words they learn in their new words and their meanings in their own dictionary. For this purpose, some suggestions were made about the acquisition of a book. Students were given an activity 
called "I Learned and Feel" for their textual meaning. This activity was held in two dimensions, the first dimension of the meaning of the text, there are three questions. On the first question, appeal, text and character were asked. Student responses to this question are as follows:

"Young people are addressed to us. At the same time, characters tend to commit crime. Family members, society." (Emine, activity file, p. 3).

"It is addressed to people. It is addressed to people for the peaceful life of people. It is mentioned about the youth and the bad characters." (Çağrı, activity file, p. 3).

As we have seen above, Emine and Çağrı showed a social point of view about the target mass of the text. On the other hand, Mehmet stated that Demir and Ayşenur had a more restrictive point of view in the target mass of the text. In the question "What is the topic in the text?", It was seen that the students gave answers with similar viewpoints. Mehmet's statement reflected the perspective of other students:

"He wants people to approach each other with love and wants them not to do evil." (Mehmet, activity file, p. 3).

When we look at the answers to the question on the main idea of the text, it is noteworthy that nothing different from the statements made about the text was presented. It appears that the students were not competent in expressing the main idea. It created awareness among students regarding this situation; the difference between the main idea and the topic was explained. The main idea was given information about the sentence stating that consists of a single jurisdiction. At the end of the same day, he shared the following in his student journal, Tülay:

"I learned a lot of new things, for example, but I was not able to comprehend what the main idea was, but through this practice I understood better." (Tülay, student diary, 04.11.2015).

After these questions about the more information dimension of the text, they were asked what they felt while listening to the text. Apart from the Cagr1, all the students seemed to reflect their own emotional worlds. Cagrı expressed itself by empathy. In order to be able to see clearly the size of the text, which influenced the students, the students were asked about the points that affect them in the text. All students, except the Cagri, stated that the chorus part affected them; but Çağrı said that he felt a sense of responsibility instead of feelings like sadness and joy in the interpretation of his other friends. Thirdly, the students were asked about the purpose of writing this song. The students described rap music as a social doctrine and a didactic text type. In connection with this, students were asked about the relationship between text and society. The answer of Ayşenur is as follows:

"There is not much difference between the topic covered in the song and society life. There are still a lot of people doing bad things. But there are those who do good work." (Aysenur, activity file, p. 4).

All students stated that rap music organized society. Differently, Aysenur described rap music as a reflection of the society. The first lesson with this activity was final. At the end of the day the research process reflected in the research log as follows:

"Today was the first lesson. The students said they liked the activity papers very much; they even use expressions that express liking as "super". Students have revealed their interest in rap music. They expressed their ideas about the songs of Ceza and his songs they liked. At the stage of interaction, I noticed that many of the students recite the song when I opened the song." (Research diary, 04.11.2015).

As seen in the research diary, it is noteworthy to state that the students took a positive attitude towards the course content and showed an attitude towards the chosen text.

\subsubsection{Interpretation}

In this step, it was aimed to analyze the content of the student text and the text in depth. Two activities were conducted for this purpose. The first was "The Revolt of Rap Music". In this activity, the sample sentences were given in the text and students were asked to write the statements that correspond to the bottom of the sample sentences. The students expressed their views on the sample sentences. The answers given by Tülay are shown below as an example:

"Do not restrict freedom."

"Crime is a very bad thing, people are dragged here and never get rid of it again."

"The crime is not something to love, it is not for putting on air." (Tülay, activity file, p. 5).

On the basis of the sample sentences in this activity, the students were finally asked about their views on what kind of music rap music was. Looking at the expressions of the students, other students than Tülay viewed rap music as a teaching message. Tülay took rap music in a linguistic context and expressed the influence of her simple expression on it. The second event under this step was the activity called "Rap music". In this activity, 
the aim was to develop students's creative speaking skills. For this purpose, students were asked four questions based on interpretation of rap music. The first question of the language used (words, sentences, etc.) what is the source, which is inspired from the form. Tülay, Mehmet and Demir about this question, the language was the source of the language of the text. At the end of the lesson, the notes reflected in the research diaries are as follows:

"In this lesson, interesting ideas emerged. One of the students who said that the origin of the language was society was trying to question the relation between society and language. There were also good discussions on writing language and speaking language. A student has developed because he finds Sumerian writing, he said. Another student said, "What is the relevance of the writing to talk?" It is evident that students are forced to associate with each other. In relation to language arts, students gave examples of sequences from popular culture texts. He gave his opinion on the use of language of Türk Mall. A string that is triggered by the RTÜK in terms of language use is not even aware that the language is corrupt and wrong. Because the characters are cute and funny, they do not even need to be questioned. I think that this awareness has increased thanks to the discussions on the lesson." (Research diary, 09.11.2015).

\subsubsection{Reconstruction}

The students were instructed to write in "creative writing" in order to support the topic of the sub-theme, which was the main text in the song of Sevgi İsleyin of Ceza. Students were asked to write their own lyrics, adhering to the main text. In order to perform the event, the class was groups of four according to the cooperative learning. In terms of guidance, theywere asked to take the following steps into consideration:

Each group selected a group graffiti through a web 2.0 tool, named graffiticreator. An example of graffiti of one group names in accordance with the lyrics can be shown as follows:

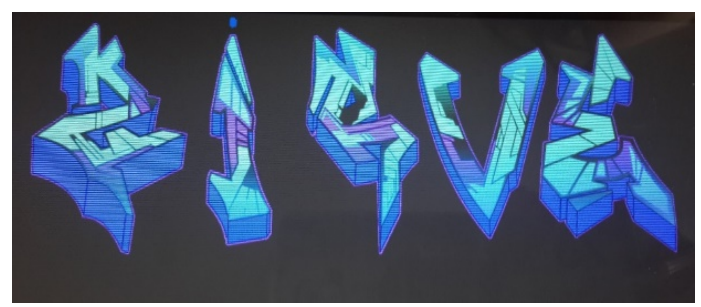

Figure 1. An example of the group names graffiti

Then each group created their own song and shared it with their friends. They edited their texts in the direction of criticism from the other groups in lesson and gave their final state. This process of the course reflects on Tülay's diary as follows:

"Our friends criticized us after reading rap lyrics. We decided to go out of these criticisms and organize our rapist." (Tülay, student diary, 11.11.2015).

The students outside Mehmet and Çağrı shared information that the course was a didactic; but the two concerned students stated that they did not learn anything, even though they thought it was an activity that addressed listening, reading, speaking and writing skills. On the other course, four groups consisting of key participants decided to chose a section of the band members.

"Those who bring crime to habit, those who see love as unnecessary.

It seems dark, but the end is dark.

Love work, respect, this road is brilliant.

Breaking is the heart of anybody, their stealing life.

Remember, no one is for sale.

Rather than commit crime, it plays tight." (Shadow group, activity file).

Finally, the students made a videotape of their songs with Vcasmo web 2.0. This process is reflected in the teacher observation form as follows: 
"These kids are making their own rap music by writing his own lyrics. They look very excited. The whole class doing handbrake percussion. They applaud each other at the end of the lesson." (Observation form, 17.11.2015).

Along with this activity, planned goals and outcomes belonging to the sub-theme of Human Love were fulfilled before the sub-theme named as Homeland Love. But before that, meetings were held with the group members who were dissatisfied with their groups. Another group was consisted with the unsatisfied students with the approval of the validity committee and the Turkis teacher for the next group work.

\subsection{Homeland Love}

The research process related to this sub theme was shown as 7 lesson hours in the Turkish language lesson year plan; but it took 8 lesson hours because of some disruptions in the research process. The aims and outcomes of this lesson's Turkish language lesson were taken directly as the annual plan showed. A total of 8 activities related to this sub theme were carried out.

\subsubsection{Preliminary Information}

The section consists of two activities. The first activity was called "Comic Novels and Feelings". This activity aimed to determine their comic book choices. The "Draw Super Hero" activity was intended to make students choose their superheroes and explain why they chose such a superhero. This activity identified stereotypes of superheroes in their heads. The first question of this activity was how Tülay and Ayşenur were influenced emotionally while reading a comic book. On the other hand, Cagrı and Demir stated that they did not read comics. In the second activity, "Draw Super Hero", students were asked to choose their own superheroes and explain why they chose such a superhero. As an example, figure 2 below demonstrates one of the superheros chosen by the students:

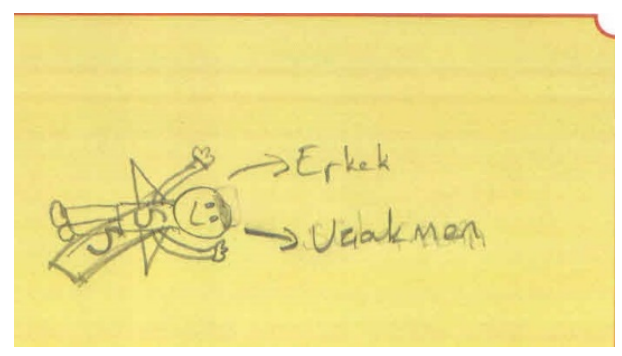

Figure 2. Çağrı's Superhero

Çağrı related to this superhero named Plane Man, "Because this character is normally male. I liked Superman's hero. I draw from that face." (Cagrı, activity file, p. 9). When we look at the superheroes and explanations drawn by the students, only two students are female superheroes. The reason for this is that the superheroes will be men, and even a male student other than the key participant students has made the following statement:

"I think, superheroes are not better; because my teacher is breaking his fingernail to do something right: My moon is broken. I can do this with" (Research lesson, 20.11.2015).

In the course of this lesson on superheroes, the situation is reflected in the following way:

"I wanted students to draw superheroes. Almost all of the students had drawn their superheroes as men. When I ask why, superheroes are in the form of being male. The sexist approach in the students surprised me. In fact, this point of view was that they saw women as weak. For this reason popular cultures are not different from the world they have created in them" (Research diary, 20.11.2015).

\subsubsection{Interaction}

At this stage, a comic book called the Justice League was examined. They were asked to review the visual of the text. Then, before proceeding to reading the text, students were asked four questions in the "Text Inquiry" activity. In the first question, students were asked whether they read the text "Justice League" before. All of the students stated that they did not read this comic book. Secondly, they were asked why they would read this comic book class. Apart from Ayşenur, all the students stated that they would read for fun and activities. Ayşenur said, "I think we will read how people are just because this comic book is about justice." (Aysenur, 
activity file, p. 10). Students are then asked to state their opinions on the text by moving from the title and the visuals. The explanations from the students are as follows:

"It seems a bit more relevant to men, but I like adventure." (Tülay, activity file, p. 10).

"It may be related to the justice of the people because the Justice League is called." (Ayșenur, activity file, p. $10)$.

Finally, students were asked if the comment would be the same when everyone read the text. All of the students also stated that their interpretation wouldvary because everyone thinks differently about the world of thought. It is thought that Emine's views on this subject are quite interesting:

"Everyone is created differently, no one is alike. Everything else has a difference with everything else in the analogy." (Emine, research video, 20.11.2015, 04: 45-04: 58).

\subsubsection{Persective}

At this stage, the comic book Justice League, which included superheroes most admired by children, was read once by the researcher. Then they were taught with the word chorus method to improve the student's ability to work in groups. For this, the class was divided into five groups and each group reads a section of the text. Students must pronounce the words correctly before they read; pay attention to the tune; they were warned to emphasize, toning, pausing and reaching where necessary. It was desirable to read the unkown words by marking words and phrases. They were to write in their books by estimating their meaning. They were encouraged to use the Turkish dictionary to check the meanings of the words they estimated. Students were asked to choose samples from the comic book. The choice of these acts and their verb forms were provided. Then, they were required to find expressions that lead to associations using outside the meanings of the text. They were asked which events they were referring to, concepts. The evaluation of these studies on semantic and linguistic knowledge reflect in the research diary as follows:

"I got this lesson language information activity. One moment they become serious. They left their place in a different order of seriousness to express themselves comfortably in previous lessons. Normally they would always try to join in a lesson; each of them answer questions in their own world of thought. But when they were activating the grammer activity, they became silent. All of this is because of the meaning that Turkish lessons remind. According to them, the Turkish language lesson equals the grammar test; because they think that the path to the TEOG exam passes through grammar. The reason for this is that both the education system and their families have to take the TEOG test as a measure of success." (Research diary, 24.11.2015).

After the semantic and linguistic activities, questions about the meaning of the text were carried out. In these questions, the subject of the text, the place of the event, the hero of the text, the team of the Justice League, and the main idea of the text were asked. The participants gave almost similar answers since the objective information in the text was directed by questions. Only answers about the main idea was varied as follows:

"It might be to keep fair the America and protect people from bad events." Aysenur, activity file, p. 11).

"The main idea of the Justice League comic book is to save the invasion of the aliens." (Mehmet, activity file, p. 11).

Another remarkable point in the above example is that the difference between the main idea and the subject is still unknown. But the difference between the answers to the main idea of the previous text and the answers to the main idea of the text of this week is the use of one judgment statement. In the previous text, there are expressions that give more than one judgment about the main idea. However, in this text, it is seen that they have included the culprits which inform the one judgment about the main idea. In the second part of the perspective activity, four questions were asked about the effect of the text on students. The question is, what is the point of affecting the text. Cagrı has stated that there is no point in this question that affects itself. The second question concerns the purpose of the text. Ayşenur, Cagrı, Mehmet and Demir emphasized the purposes of popular culture texts's amusing and commercial anxiety. On the other hand, Emine bases the purpose of creating comics in a different way, as seen below:

"Usually, children and teenagers are reading comics. It may be that superheroes are seen as idols. By defeating most of the bad heroes, he may have tried to convey the message that evil will not be reached one by one." (Emine, activity file, p. 12).

The answers given by the students to the target group of the text are almost similar. According to Ayşenur, Tülay, Emine and Demir, the target mass of the text constitutes people of all ages, children, adolescents and adults. But Çağrı and Mehmet, unlike the others, gave the following answers: 
"It is addressed to earthlings." (Cagr1, activity file, p. 12).

"I think this comic book has been addressed to people who harm others." (Mehmet, activity file, p. 12).

When we look at the comments on the lesson in the student's diary, it is seen that the students have a negative attitude about the text questions. As seen in the commentaries, it is thought that the questions related to the text have no value for eyes of the students. Looking at the observational form data, the positive observations of the students against the course were seen in the reading phase of the text. No significant observations were made about the questions related to the text.

\subsubsection{Interpretation}

There are two activities at this stage. First, students are asked to perform an activity called "Pictures and Writings". Aysenur, one of the key participant students said "I used these expressions, because the pictures, movements, behaviors, posture styles tell me that I should write them. I wrote these statements because the Justice League was always created to find justice." (Aysenur, activity file, p. 14) Ayşenur's text is shown in Figure 3.

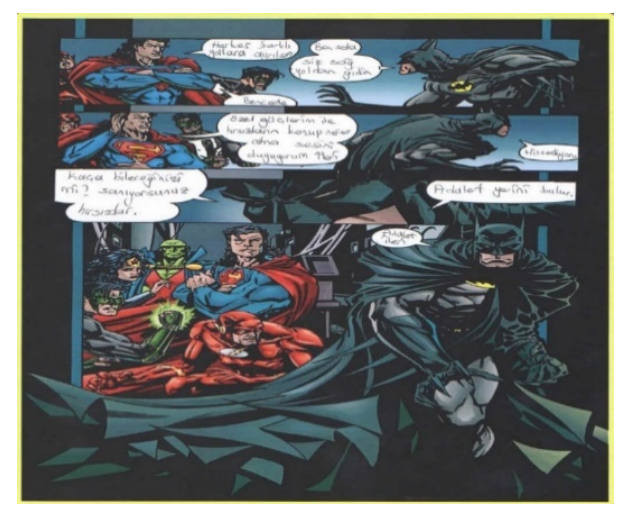

Figure 3. Aysenur's gap-filling comic book

It is seen that all the students except Mehmet filled the gaps inspired by the gestures and mimics on the comic book. After this activity, students were asked why they were using the text and the picture at the same time on the comic book. Given the comments received from students, the use of text and picture in comics books remarkable, entertaining and meaningful support for the text. After this activity, the fourth event called "Super Heroes" was passed. In this activity, three questions were asked to develop a critical perspective of the students. In the first question, they were asked whether they should admire the superheroes and whether there is a relationship between their bodies and their clothes. The answers from the students are as follows:

“The more attention the hero's clothes attract, the greater her admiration. Because people are usually interested in the attention-grabbing character. Visuality is important in superheroes." (Emine, activity file, p. 15).

"The clothes of superheroes show their strength." (Mehmet, activity file, p. 15).

When you look at student reviews, you see that superheroes have the power of their influence. They see their clothes and their physical structures as complementary to that power. In classroom-related discussions related to the activity, the following expressions are relevant to this topic by Cagri:

"There is normally no power in Spiderman. When a person wears that costume, it becomes "Aaa ...!"' (Cagr1, reserach video, 01.12.2015, 09: 41-09: 44).

The students passed on to the second question after thought-provoking debates such as "Is it so important for the appearance of the clothes and the physical appearance to look really strong?" In the second question, the students were asked whether there was a relationship between being a superhero and becoming a woman or a man. Tülay, Mehmet and Demir stated that there was a distinction in favor of men about superheroes. Emine, on the other hand, expressed dissatisfaction with the discrimination and made the following statement:

"In comic books, it's usually both male and female characters. However, there are few female characters. This shows that there is an inequality." (Emine, activity file, p. 15). 
After discussions on this subject, Mehmet insisted, "My superhero is strong and muscular." (Mehmet, research video, 01.12.2015, 19: 44-19: 47). The Çağrı states:

"In fact, in normal life, for example, women who died like her husband become heroes, but even if they have no special powers, they work, look at their homes, and then look after their children. They become like superheroes." (Cagr1, application videosu, 01.12.2015, 23: 50-24: 04).

Finally, students were given the opportunity to think about the difference between the violence imposed by the characters who were struggling with the violence of superheroes. Except for Emine, all students were righteous, expressing admiration for the superheroes they had shown. Observations on this lesson reflect this:

"Students are aware of exactly what the messages given by moving texts are. They explain how the hero's attributes in her text evoke them and how they relate to them by giving examples of heroes." (Observation form, 01.12.2015)

\subsubsection{Reconstruction}

At this stage, you have information about the language and expression features of comic book; students who were supposed to gain a critical view of superheroes were asked to build their own superheroes. Then there is a real or imaginary, and they have set themselves to solve problems in Turkey were asked to produce through their own superheroes. Before moving on to making a comic book, students were asked dentify a message for texts they will create; form their texts to address a specific target group; the target group should be taken into consideration; define their objectives when producing the text clearly; the text should be in compliance with the rules of the standard Turkish language. The comic book was created using the web 2.0 tool named pixton. One of the group comic book is shown in Figure 4:

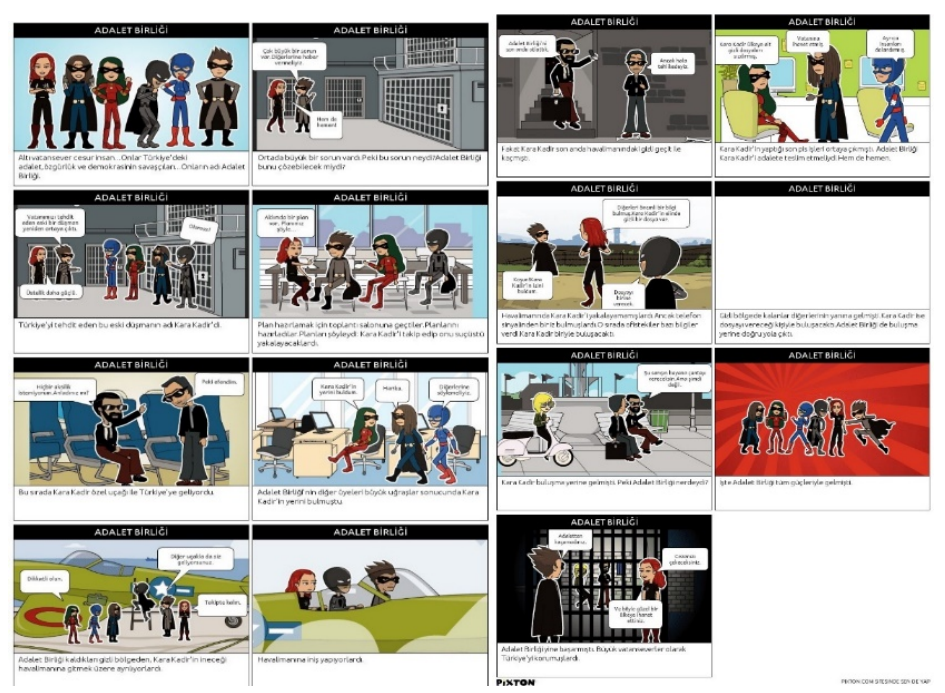

Figure 4. Comic book of the second group

As seen in Figure 4, the second group implemented a character design that was not based on gender discrimination. The group, which developed a violent event pattern, chose the clothes of the superheroes with more covering costume. In addition, the event pattern was not with extraordinary powers; with the technological possibilities of the present age. After the activity, each group member's comic book was evaluated by the other students in the class. Following this evaluation made in terms of the use of standard Turkish language, all groups were given the last of their comics, as seen Figure 4. Then they sent you the latest version of the text by mail to the researcher.

\subsection{Family Love}

These sub-themes related to the research process, shown as 7 hours of Turkish language lessons in the annual plan; the research process lasted 7 hours. The aims and outcomes of this lesson's were taken directly as the annual plan was shown. A total of 7 activities including a preliminary information section on this sub theme were realized. While the Family Love sub-theme was being processed the cartoon called Sponge Bob was used. 


\subsubsection{Preliminary Information}

In this section, students had two activities. The students learned about the existing information about cartoons with activity named "What is Cartoons?". At the same time, their attention was drawn to the subject. Ayşenur saw cartoons as merely entertainment. However, Demir, Çağrı, Emine and Tülay saw cartoons as a carrier of a certain message and made their explanation in this respect. It can be said that the students started to see and evaluate cartoons as a popular culture product. In fact, in Mehmet's statement, it is seen that this situation went as far as secret transmission:

"I loved watching cartoons, but as I grew older I started not to like it. But some can be fun, and some cartoons can have "subliminal" messages. This event can also affect individuals negatively." (Mehmet, activity file, p. 17).

After this activity, the second activity called "The Magic of Cartoons" was conducted. In this activity, students were asked about the seductive and impressive aspects of cartoons. Looking at student reviews, it turns out that cartoons were not a specific target group and were products that appealed to everybody's life. It is noteworthy to say that the students watched that cartoons they liked. Another point that draws attention is that they did not indicate any negative thoughts about cartoons. At the end of the day, Emine's interpretation about lesson reflected in her diary as follows:

"I was very interested in the cartoon story. Because I love watching cartoons. I even watched English language on the internet because a line was not published in Turkish language in the second and third seasons of cartoons. That's why the cartoons are so interesting." (Emine, student diary, 04.12.2015).

\subsubsection{Interaction}

At this stage, the main text, Grandmamma Kiss, was used. The text was played quickly before being viewed. Students are asked to review their visuals. Then four questions were asked to the students before the text was read. The first question is that they have not watched and watched the cartoon before. Demir "I have never watched the cartoon named Sponge Bob before. But it could be a cartoon about what the subject of a sponge is about." (Demir, activity file, p. 18). In the second question, students were asked that cartton in the second question, it was asked what purpose cartoon would be watched. Çağrı has been approached entirely in terms of a popular culture text and has been watched for sub-messages as follows:

"We will process this message to find private messages." (Cagrı, activity file, p. 18).

A different opinion came from Ayşenur as follows:

"We can watch for positive behavior and can tell speak Turkish effectively." (Aysenur, activity file, p. 18).

While Aysenur was a student who constantly questioned the relation between the texts used and the content of Turkish language lessons in the first lessons, this interpretation shows that she evaluates her Turkish language lessons by associating popular culture texts. After this question, the students were asked whether they could teach or not to teach them something about the cartoon that would be processed as text. Although all of the students stated that they would be of an instructive, Mehmet was in the following opening:

"It only makes me entertain. I do not want me to have an idea." (Mehmet, activity file, p. 18).

This interpretation of Mehmet is thought to have originated from a critical point of view towards the cartoon. Cartoons as popular culture texts mean that they are thought to be a text that provides a good time but is consciously distant from instructive. Finally, students were asked what points they would affect in the cartoon and what would affect if they were happened. Male students indicate that fear, excitement and moving scenes will affect themselves; girl students stated that they preferred entertaining scenes.

\subsubsection{Percpective}

The Sponge Bob cartoon, the 12-minute section called Grandmamma Kisses, was shown to the students. When the text has come in the last three minutes, listening / watching has been interrupted. After that, students are asked to indicate their thoughts about what might happen. After the opinions of the students were taken, the contents of the text were listened / watched. Later on, they were provided with selective listening / watching method and second time listening / watching so that they could listen again for their purposes. The student responses to the text are reflected in the research diary as follows:

"We have made the preliminary information part of the sub-theme of Family Love for students of the past course. In this lesson, I took a class that projected the students to watch the Sponge Bob cartoon, which is the listening / watching text. Before they begin watching cartoons, I warned them about finding the answers to the questions in 
the first activity. We started watching cartoons. All the students, including the Turkish language teachers, watched the cartoon very carefully. It was obvious that they enjoyed too. They even wanted to watch it again for the second time." (Research diary, 09.12.2015).

After listening / watching the text, students are asked to set up sentences indicating cause and effect relation to the events in the text. Regarding the cause-effect relation, Tülay established the following sentence:

"Everybody is laughing in places where SpongeBob works because of her kiss on the forehead." (Tülay, research video, 12.09.2015, 13: 55-14: 00).

Although the use of a cartoons as a listening / watching text differs from that of the students, it is seen in the above sample examples that the activities associated with the Turkish language lesson show the necessary care, such as cartoons, text of a Turkish language lesson. In the lesson, the words "funny-ridiculous, intelligent-old, old-aged" selected from the text were written. The student's opinions about the meaning relation between these words were taken. It was reminded that the students were told that "the spellings are different, their meanings are the same words, synonyms". Again, words, "burning, kissing, growing" selected from text written on the board. Students who want to make an activity should divide these actions into their annexes and their roots; They are asked to indicate their tense and their personal ending. The seriousness of the students during the event grammar is described as follows in the research diary:

"Students are very relaxed as far as the introduction of grammar is concerned. It is certain that they care, but it is not that importance that comes from them; it is as important as they have to give." (Research diary, 09.12.2015).

The importance that the students give to their grammar activities reflects in the research diary. It has been observed that this situation has not changed since the beginning of the research period. In fact, students were not aware of the importance of reading, writing, speaking and listening skills for Turkish language lesson. After the grammar activities, the students were asked four questions in the second activity on what they learned from the text. These questions seemed to give students almost the same answer. The third question of opinion on the subject of the text is different from each other. However, it is noteworthy that the opinions of the students on the main idea are as follows. Students learn the distinction between the subject and the main idea; but it is thought that they can not show it in practice.

"We know we are not a kiss baby. We know that even adults may be grandmothers, but we are still adults." (Tülay, activity file, p. 18).

"It is not something to be embarrassed if we like a person or an elder. It is not necessary for us to be a baby for love." (Emine, activity file, p. 18).

After understanding of text, the students were asked to set up the cues, starting with "if I were ..." by replacing them with Sponge Bob. Mehmet, in the following explanations:

"I would not act like Sponge Bob, my teacher. So I would explain the events to grandmother. Sponge Bob did not tell the situation here." He said, "Grandmamma, I'm grown now. But I wanted him to do better by telling the situation." (Mehmet, research video, 09.12.2015, 23: 05-23: 20).

It is thought that students interpreted the situation by associating it with their own family environment, as seen in the above explanations that students made in activities.

\subsubsection{Interpretation}

Students are given the opportunity to express themselves through guided speech to explain their feelings and thoughts. For this purpose, students were asked three questions in the first activity of this step called "Equality of Women and Men". On the first question, SpongeBob's grandmother was taken in opinion on how he handled the cartoon as a woman. After this stage, the reconstruction stage has been passed. At this step, the students have the opportunity to present the information they have obtained as behavior.

\subsubsection{Reconstruction}

Students were asked to write their own cartoon scripts on the cartoon named Grandmother Kiss. For this, the class is divided into groups of four, as is done in the reconstruction events on the other sub-themes. The scenario that the students have prepared is as follows:

"SpongeBob will protect your grandmother? Or...

Would he say no to inequality?

Would SpongeBob choose fun or family? 
You will learn this soon.

Patrick: Hello Spongebob. How are you?

Sponge Bob: Good, thank you. How are you?

Customer: Can we get a napkin?

Patrick: I'm fine too. I've been asking a Iskender kebab...

Sponge Bob: Yours is coming. Okay, I am bringing it right now.

Patrick: There's a plate here, Spongebob. Will you take this?

Sponge Bob: Here, enjoy your food.

Patrick: Thank you.

Grandmamma: SpongeBob, were you here too? What are you doing are you ok?

Sponge Bob: Good, grandmamma. I'm cooking food. What are you doing?

Grandmamma: I'm fine. Will you do me one too?

Sponge Bob: I'm doing it right now.

Patrick: Take it, Sponge Bob. It is over.

SpongeBob: Thank you, enjoy.

Grandmamma: Patrick, what are you doing, kittens?

Patrick: I'm fine too, Grandmamma.

Grandmamma: I will bring you cookies tomorrow.

SpongeBob: Take it, grandmamma.

Grandmamma: Thank you. (Eat your dinner). Yeah, come on, you put this on, let's go to have fun. What shall we do?

Patrick: I think we should play basketball.

Grandmamma: Okay. Let's take a walk.

(They come to the basketball court.)

Patrick: Hello, are you the basketball officer?

Officer: Yes, this is me.

Patrick: We want to playing basketball. How many pounds per person?

Patrick: We were three people playing basketball. How many pounds per person?

Officer: 10 pounds per person. Grandmamma can not play. Not for the ladies, but for the men only.

Patrick: Why? We want our grandmamma to play with us.

Sponge Bob: This is not equal. Women or men are not superior to each other.

Officer: Unfortunately, I think so, but there is nothing to do.

Grandmamma: Can I talk to your boss?

Officer: We do not have a boss but you can petition if you want. Grandma: I want to use my petition.

Officer: $O K$.

Grandmamma: Give me one paper.

Officer: Here. I would have liked it, but I did not understand why.

Grandmamma: Give this to your boss. It must be equality.

Officer: $O K$.

Grandmamma: Well, we do not. Let's go to the funfair.

Patrick: Are you the funfair officer?

Officer: Yes, it is me. Here you are.

Patrick: We want to mount in fear tunnel. 
Officer: Okay, but unfortunately you will be the two without your grandmother.

Patrick: Why? It needs to be equal.

Grandmamma: Yes, I am getting a raw deal.

SpongeBob: That's what happened in the place we went to before. Please give us some kindness.

Officer: $O K$.

Grandmamma: Well, thank you very much. Come on, man. I'll be the first one." (Second group, research video, 10.12.2015).

The second group, which was written in the script, as in the first group places cultural elements (like İskender kebab) are outstanding. This group, according to the other group, handled the inequality of women and men based on rights and freedoms. The scenarios were presented to the class by each group. It has been criticized in terms of the use of standard Turkish language and the fact that it does not reflect the women's, man's equality and Family Love. Scenarios were organized in the direction of criticism. Later, each group was asked to dramatizate their scripts and convert them into digital stories using the web 2.0 "animoto". Finally, each group edited their videos and shared them.

\section{Discussion}

The use of popular culture texts in education has been discussed in the literature because it is known that they include contents that could have negative effects on children and teenagers. However, it would not be appropriate to generalize these negative effects. As it can also be seen in the findings section of the current study, it is advocated that among those popular culture texts some of them could positively influence academic outcomes of students. It is considered that the reason behind the negative view against popular culture stems from adults' unfamiliarity with popular culture. Nevertheless, the content of today's children's games have relation to popular culture texts (Marsh \& Millard, 2000). Accordingly Grugeon (2005) stated that students have been heavily exposed to popular culture texts out-of-school and the texts known by students could be positively used in education. Besides, according to Willett (2005) popular culture positively influence teaching and learning process by means of providing enriched classroom environment. Accordingly, Morrell \& DuncanAndreda (2006) expressed that if students are given responsibility to construct their own realities and disrupt negative perception on popular culture texts, they could learn how to develop narratives. In addition, Hall (2012) whose perspective on the learning outcomes and goals of popular culture's skill areas is similar to the current study's perspective advocates that students need to study on to determine racist, sexist, and the cultural clichés presented in popular culture texts. Furthermore, he noted that students need to reckon on not only to what extent the clichés are attached importance in the texts but also whether they attach importance to those clichés in their daily lives. When it is viewed from this perspective, and taking into account the adverse effects on expert opinions, it can be used in the Turkish language lesson of popular culture texts.

In the literature the use of popular culture texts has been elaborated in two different ways: popular culture related to curriculum and popular culture as curriculum (Schultz \& Throop, 2012). This study do not have any attempt to develop curriculum related to popular culture. Rather, the current study aimed to relate existing Turkish language lessons to popular culture texts. Heath (1983) acknowledge the necessity of integrating popular culture text to a curriculum related to language education. In line with this purpose, the investigation of popular culture texts in the course of action research study has two folds. The first one isTurkish language lesson with popular culture texts, and the second one is Turkish language lesson about popular culture texts. Even though secondary school students have experience in reading, they do not comprehend the difference between reading for fun and reading for academic purposes (Moje ve Sunderland, 2003). Many of them acquire superficial knowledge of texts without hesitating to think of their source or supported viewpoint (Marshall \& Klein, 2009). In this study, it is intended that students to both have fun and gain information while reading popular culture texts. It is also aimed that students to gain critical thinking skills. In this regard Beavis (2014) argued that popular culture texts could be used in both mother tong education in order to develop basic language skills and they can be used to link out-of-school experiences. Marsh et al. (2005), in their study, revealed that popular culture texts merge in-school and out-of-school experiences. In his study on 7th graders mother tongue education, Stevens (2001), who approaches popular culture texts within the contexts of mother tongue education and critical literacy, links popular culture texts with learning process through critical perspective. With a similar perspective, Morrell\& Duncan-Andrade (2006), in their study conducted with secondary school students, found that popular culture texts not only develop critical thinking skills but also improve critical writing skills. The results of many similar studies linking popular culture with mother tongue education (see Alvermann, 2012; Alvermann \& Xu ve 
Marilyn, 2003; Bausell, 2006; Buelow, 2011; Hall, 2012; Lawrence, \& McNeal ve Yildiz, 2009; Marsh, 2006; Schoon, 2010; Skinner, 2006, etc.) support the findings of this study. In this study, mother tongue education outcomes were aimed to teach with popular culture texts; besides, investigating texts and evaluation skills were aimed to achieve with popular culture outcomes. From this aspect, primary school Turkish Language Curriculum (6th-8th grades) corresponds to the curriculum.

Adaptation to out-of-school experience, meeting mother tongue education outcomes, investigating popular culture texts and along with evaluation, students produced their own popular culture texts with the information obtained in the step of reconstruction. The findings of the study correspond to the general aims of Turkish Language Curriculum (1st-8th Grades) (2015) which was renewed in this aspect and planned to be put into practice incrementally over the following years. Throughout the process of 6-week action research which was designed with these perspectives, Turkish language lesson outcomes were aimed to be attained by associating with popular culture texts such as hip-hop music, comic books, superheroes and cartoons.

In the first sub-theme, hip-hop style music, which is the popular culture text is also used for skill areas of the Turkish language lesson. However, its purpose related to popular culture texts (identification of the components of popular culture texts, self-integration with popular culture texts, using of language in popular culture texts, evaluation in terms of social and content, producing of new texts thanks to popular culture texts) and outcomes were also achieved. As regards the Turkish language lesson related to rap music, the studen's opinions focused more on establishing a relationship with the non-school life. Students expressed that rap music is part of their daily life and that this practice, which they perform in school, resembles their out-of-school life. Students who pointed out that the texts and activities were interesting also reflected in the student's diary that contributed to the development of language arts. Alim (2007) and McCrary (2005) stated that in their work, the introduction of hip-hop texts into the lesson has improved student's reading and writing skills. Kelly (2013) also proposed a curriculum to develop a critical perspective on hip-hop culture, which was utilized in language teaching, as well as in the study of hip-hop, in its study of mother language teaching. In addition to this, studies on hip-hop culture (Forell, 2006; Hall, 2012; Love, 2014; Rickford \& Finegan, 2004; Sitomer, 2006, etc.) support the findings of this research in terms of contributions to language arst and critical literacy. There are very few studies on language education in Turkey with rap music. One of them is a work by Aksoy (2012) based on the opinions of lullaby and tale in the form of rap music and transmission to future generations. This work of Aksoy was similar to the findings of this research in terms of observing the intertextuality. Because, in this research, the students produced their own texts by including the critical perspective of the popular culture in the process. Another study is the study by Asal \& Vural (2011), which tried to give a critical view to the elements of violence in rap music. In this study, rap music is taken from a totally negative point of view. This does not support research findings. Music plays an important role in making the teaching effective (Sever, 2006). In addition, neither of these studies is intended for mother tongue education.

The second sub-theme is popular culture texts, comic books and superheroes. During the approximately one-and-a-half-week action research process in which this text takes place, we will be able to reading (apply reading rules, understand and analyze texts, enrich the vocabulary), speaking (apply speech rules, prepare speech), writing (apply writing rules) and grammar (understanding and application of information and rules related to word types) skills. At the same time, popular culture aims related to the purpose and outcomes of Turkish language lesson about popular culture (recognition of the components of popular culture texts, evaluation of popular culture texts in terms of language and content, producing new texts / meanings through popular culture texts). It is seen that comic books are suitable materials that can be used as teaching material at studies in the literature (see Bitz, 2010; Boerman-Cornell, 2013; Dalacqua, 2012; Danzak, 2011; Gavigan \& Tomasevich, 2013; Jacobs, 2007; Kilickaya \& Krajka, 2012; Mei-Hung \& Boe, 2012; Rapp, 2011; Schwarz, 2006; Wissman \& Costello, 2014; Zimmerman, 2008), In these studies comics are usually developed in the skills of reading and writing; but also in the development of critical thinking skills. For example, the study that Kersulov (2016) made is one of them. According to Kersulov, who designed his own comic books in classroom practices, comic books are important texts in the development of reading and writing skills. A similar view that comic books are important contents in improving reading, writing skills and creating a student-centered classroom environment is also revealed in the study of Bakis (2012). Referring to studies conducted in Turkey Cihan's (2014) findings of studies that have been done with this study's findings are consistent. However, Cihan (2014) presented a theoretical framework for his outcomes by studying only one of the outcomes of grammar in his study. It differs from this work, which is directed towards practice and deals with all the skills. Can, Türkyılmaz \& Karadeniz (2010); İşcan, Arıkan, \& Küçükaydın (2013); Karatay (2007) pointed out that comic books should be taught as a reading text in their studies. These studies support the findings of the research. 
In the third sub-theme, cartoons, which is the popular culture text is used for outcomes of listening (to practice listening rules, to understand and analyze listening / watching text, to evaluate what they listen / watch, to enrich their vocabulary); writing (planned writing, produce different types of texts, writing and punctuation rules); speaking (making prepared speaking); grammar (understanding and application of information and rules about word types). Since cartoons have an important place in the transfer of cultures (Alicenap, 2015; Turkmen, 2012), it is also important to understand popular culture objectives related to aims and outcomes in Turkish culture (recognition of components of popular culture texts, social evaluation of popular culture text, evaluation in terms of content, producing new texts / meanings through popular culture texts). Fowles (1970), the cartoon has seen both films have used as a tool in teaching both languages as transmitters of culture. He has matched the humor elements in cartoons with the cultural structure of the society. In this regard, the study supports the findings of this research. With the similar perspective, Müller-Hartmann (2007), dealing with Disney cartoons, used them as lesson material in the development of language skills in mother tongue education lessons; but also tried to gain a critical perspective on popular culture texts (cultural sciences, stereotypes, sexist approach, etc.) to students. The sexist approach in cartoons was also seen in the work of Kalayc1 (2015). He also stated that he was trying to convey a sexist approach from clothes to movements. This study is similar in terms of enriching the word presence with study of Bursalı \& Ünal (2015); Karakas \& Sarıcoban (2011); Bektas \& Sahin (2011); Karakuş \& Baki (2015). Popular culture texts in the research cited in Turkey are just used as a tool in the course content or are just taken as a given that the text of popular culture for production purposes. In this sense, this research does not coincide completely. Because, in this research, each popular culture text shows both an instrumental feature in the transmission of language skills and a content feature that is centralized and analyzed as popular culture text.

The following suggestions can be made from the findings of the research:

- The Ministry of National Education may develop a questionnaire or interview form to identify popular culture texts that constitute the out-of-school life of the students. It can provide this measurement tool to teachers in their classes during the first week of each semester. The determined popular cultural texts can be used for student to do more actively to Turkish language lessons and to increase their academic success.

- In the light of the findings of the study, the outcomes about the popular culture texts which increase the motivation of the students towards the Turkish language lesson and which affect the academic development of the language arts positively can be related to the outcomes of the Turkish Language Curriculum by Ministry of National Education.

- The Ministry of National Education has announced that it has been renewed in 2015, the Turkish Language Curriculum (grades 1-8). The textbooks of the program will be selected from the books suggested by the Ministry of National Education. In this regard, the Ministry of National Education may encourage the person or persons proposing the book to design course content related to popular culture texts that constitute the out-of-school life of children.

- The Ministry of National Education may suggest popular culture books as an alternative reading list, which will both stimulate literary pleasure in students and affect language development positively.

- It seems that the Turkish language lesson shows a lesson feature that is executed in the shadow of the central exams like TEOG. In this case, the Turkish language lesson is seen as being composed of grammar; reading, writing, listening / watching and speaking skills can not be awareness in the Turkish language lesson. The Ministry of Education may go to the new regulations to ensure that Turkish lessons are not merely grammar.

- In this study, Turkish language lessons and popular culture texts are associated. Separate studies can be done to see whether popular culture texts contribute only to language arts, or to provide awareness and critical view of popular culture texts.

- The study found that popular culture texts contributed positively to the development of language arts. But among the objectives of the study didn't focus on what skills the ability to contribute to contribute more and more to get where he provides could not be seen clearly. In this respect, studies can be made about which skills are more effective.

- It has been seen that the use of popular culture texts as reading and listening / watching texts in Turkish language lessons has positively influenced the motivation of the students towards the lesson. On this subject, more reading and listening / watching popular culture texts can be found or edited for their use in Turkish lessons and studies on their effectiveness can be made. This will be an important contribution to the field of listening / watching skills known as neglected field in Turkish language lessons. 


\section{References}

ABD Common Core Standards for English Language Arts, History/Social Studies: Grade 6-8. (2010). Retrieved from http://www.corestandards.org

AC History Units: Developed by the History Teachers' Association of Australia. (2015). Retrieved from http://www.achistoryunits.edu.au

Adalet Birliği Çizgi Romanı. (2015). Retrieved from https://docviewer.yandex.com.tr/

Aksoy, E. T. (2012). Ninni-masal-rap üçgeninde toplumsal eleştiri ve metinlerarasıllk. Turkish Studies, 7(3), 157-171.

Alicenap, T. C. (2015). Kültürel mirasın çizgi film senaryolarında kullanılması. Türklük Bilimi Araşstırmaları, 37, $11-26$.

Alim, H. S. (2007). Critical Hip-Hop Language Pedagogies: Combat, Consciousness, and the Cultural Politics of Communication. Journal of Language, Identity, and Education, 6(2), 161-176. https://doi.org/10.1080/15348450701341378

Alvermann, D. E. (2012). Is there a place for popular culture in curriculum and classroom instruction? In A. J. Eakle (Ed.), Curriculum and Instruction, 2, 211-228. https://doi.org/10.4135/9781452218465.n13

Alvermann, D. E., Xu, S. H., \& Marilyn, C. (2003). Children's everyday literacy: Intersection of popular culture and language arts instruction. Language Arts, 81(2), 145-154.

Animoto. (2015). Retrieved from https://animoto.com/

Aşal, B., \& ve Vural, F. (2011). Şarkı Sözlerinde Şiddet Öğesi: Aksaray İli İlköğretim İkinci Kademe Öğrencileriyle Yapılan Bir Çalışma. Selcuk University Social Sciences Institute Journal, 25, 251-259.

Bakis, M. (2012). The Graphic Novel Classroom: Powerful Teaching and Learning with Images. New York: Corwin. https://doi.org/10.4135/9781483387604

Bal, M. (2016). Popüler kültür metinlerinin ana dili eğitiminde kullanımı (Yayımlanmamıs Doktora Tezi). Çanakkale Onsekiz Mart Üniversitesi Eğitim Bilimleri Enstitüsü, Türkçe Eğitimi Ana Bilim Dalı, Çanakkale.

Bausell, S. B. (2006). Pump up the pod: Popular culture and podcasting in a critical secondary language arts course (Order No. 1435698). Retrieved from ProQuest Dissertations \& Theses Global. (305325545).

Beavis, C. (2014). Games as Text, Games as Action: Video Games in the English Classroom. Journal of Adolescent \& Adult Literacy, (6), 433-439. https://doi.org/10.1002/jaal.275

Bektaş, M., \& Şahin, S. (2011). Çizgi filmlerde atasözü ve deyimlerin kullanımı. Ankara Üniversitesi Çocuk ve Gençlik Edebiyatı Uygulama ve Araştırma Merkezi (ÇOGEM) 3. Ulusal Çocuk ve Gençlik Edebiyatı Sempozyumu.

Bektaş, M., \& ve Şahin, S. (2011). Çizgi Filmlerde Atasözü ve Deyimlerin Kullanımı. III. Ulusal Çocuk ve Gençlik Edebiyatı Sempozyumu, 5-7 Ekim 2011, Ankara Üniversitesi Çocuk ve Gençlik Edebiyatı Uygulama ve Araştırma Merkezi (ÇOGEM), Ankara Üniversitesi, Ankara.

Benson, P., \& Patkin, J. (2013). Popular culture in Hong Kong senior secondary school English curriculum: Part 1, A critical rewiev of documents and resources. Hong Kong: The Hong Kong Institute of Education, Centre for Popular Culture and Education.

Bitz, M. (2010). When Commas Meet Kryptonite: Classroom Lessons from the Comic Book Project. Language and Literacy Series. New York: Teachers College.

Boerman-Cornell, B. (2013). More than Comic Books. Educational Leadership, 70(6), 73-77.

Browne, R. B. (2006). Popular culture theory and methodology: A basis introduction. In H. E. Hinds, Jr. Merilyn, F. Motz, \& A. M. S. Nelson (Eds.), Popular culture: Notes toward a definition (pp. 15-23). Wis.: University of Wisconsin Press/Popular Press.

Buelow, S. M. (2011). Harnessing the power of students' out-of-school interests and knowledge: Integrating popular culture in a 6th grade English language arts curriculum (Order No. 3502156). Retrieved from http://search.proquest.com/

Bursalı, H., \& ve Ünal, F. T. (2015). Çizgi Dizilerin 5. ve 6. Sınıf Öğrencilerinin Söz Varlığına Katkısı. Mustafa Kemal Üniversitesi Sosyal Bilimler Enstitüsü Dergisi, 12(29), 60-74. 
Calhoun, E. (1994). How to use action research in the self-renewing school. Alexandria, Va.: Association for Supervision and Curriculum Development.

Cammarota, J., Romero, A., \& Stovall, D. (2014). 6. The Social Justice Education Project: Youth Participatory Action Research in Schools. In Raza Studies: The Public Option for Educational Revolution. Tucson: University of Arizona Press.

Can, R., Türkyılmaz, M., \& ve Karadeniz, A. (2010). Ergenlik dönemi öğrencilerinin okuma alışkanlıkları. Ahi Evran Üniversitesi Ë̆itim Fakültesi Dergisi, 11(3), 1-21

Ceza. (2010). Sevgi İşleyin. Retrieved from https://www.youtube.com/

Childs, D. J. (2014). "Let's talk about race": Exploring racial stereotypes using popular culture in social studies classrooms. Social Studies, 105(6), 291-300. https://doi.org/10.1080/00377996.2014.948607

Chomsky, N. (2007). Demokrasi ve eğitim. C. P. Otero (Ed.). İstanbul: Bgst Yayınları.

Chua, B. H. (2012). Structure, audience and soft power in East Asian popular culture. Hong Kong: Hong Kong University Press.

Cihan, N. (2014). Eğitsel Araç Olarak Çizgi Romanın İlköğretim 8. Sınıf Türkçe Ders Konularına Uyarlanması. Ĕ̈itim ve Ögrretim Araştırmaları Dergisi, 3(3), 313-321.

Compulsory Secondary Education (ESO). (2015). Retrieved from http://www.mecd.gob.es/portada-mecd/en/

Dallacqua, A. K. (2012). Exploring Literary Devices in Graphic Novels. Language Arts, 89(6), 365-378.

Danzak, R. L. (2011). Defining Identities Through Multiliteracies: EL Teens Narrate Their Immigration Experiences as Graphic Stories. Journal of Adolescent \& Adult Literacy, 55(3), 187-196. https://doi.org/10.1002/JAAL.00024

Day, C. (1999). Developing Teachers: The Challenges of Lifelong Learning. Educational Change and Development Series. ERIC veritabanından erişildi.

Demirel, Ö. (2010). Kuramdan uygulamaya eğitimde program geliştirme (13. Bsk.). Ankara: Pegem Akademi.

Dewey, J. (1966). Tecrübe ve eğitim (2. Bsk.). (çev. Sinan Akı1lı). Ankara: ODTÜ Yayıncılık.

Durukan, E. (2008). Türkçe Dersi Öğretim Programının (6-8. Sinıflar) Hedef ve Kazanımları Doğrultusunda 7. Sinıf Türkçe Dersi Öğrenci Çalışma ve Öğretmen Kılavuz Kitaplarının Değerlendirilmesi (Yayımlanmamış Yüksek Lisans Tezi). Karadeniz Teknik Üniversitesi Sosyal Bilimler Enstitüsü, Türkçe Eğitimi Anabilim Dali, Trabzon.

Education in Ireland. (2015). Retrieved from http://www.education.ie/en/

Education System in Finland. (2015). Retrieved from http://www.minedu.fi/OPM/?lang=en

Epçaçan, C., \& ve Erzen, M. (2008). İlköretim Türkçe Dersi Öğretim Programının Değerlendirilmesi. Uluslararast Sosyal Araştırmalar Dergisi, 1(4), 182-202.

Erdoğan, İ. (1999). Popüler kültür, kültür alaninda egemenlik ve mücadele (pp. 18-53). Nazife Güngör (der.). Popüler Kültür ve İktidar. Ankara: Vadi Yayınları.

Erdoğan, İ., \& ve Alemdar, K. (2005). Popüler kültür ve iletişim (2. bsk.). Ankara: ERK.

Ferrance, E. (2000). Action research. Themes in Education. Northeast and Island Regional Educational Laboratory at Brown University.

Forell, K. H. (2006). Ideas in Practice: Bringin Hip-Hop to the Basics. Journal of Developmental Education, 30(2), 28-33.

Fowles, J. (1970). Ho Ho Ho: Cartoons in the Language Class. TESOL Quarterly, 4(2), 155-159. https://doi.org/10.2307/3586186

Futbolcu Kartları. (2015). Retrieved from http://futturk.com/

Gavigan, K., \& Tomasevich, M. (2013). Connecting Comics to Curriculum. Library Media Connection, 32(1), 32.

Graffiti creator. (2015). Retrieved from http://www.graffiticreator.net/

Grugeon, E. (2005). Listening to Learning outside the Classroom: Student Teachers Study Playground Literacies. Literacy, 39(1), 3-9. https://doi.org/10.1111/j.1741-4350.2005.00391.x 
Güngör, N. (1999). Popüler kültür ve iktidar. Ankara: Vadi Yayınları.

Hall, L. A. (2012). How popular culture texts inform and shape students' discussions of social studies texts. Journal of Adolescent \& Adult Literacy, 55(4), 296-305. https://doi.org/10.1002/JAAL.00036

Heath, S. B. (1983). Ways with Words: Language, Life and Work in Communities and Classrooms. Cambridge: Cambridge University Press.

Hungarian National Core Curriculum. (2015). Retrieved from http://www.nefmi.gov.hu/english

İşcan, A., Arıkan, İ. B., \& ve Küçükaydın, M. A. (2013). İlköğretim İkinci Kademe Öğrencilerin Kitap Okuma Alışkanlıkları Ve Okumaya İlişkin Tutumları. International Journal of Eurasia Social Sciences / Uluslararasi Avrasya Sosyal Bilimler Dergisi, 4(11), 1-16.

Jacobs, D. (2007). More than Words: Comics as a Means of Teaching Multiple Literacies. English Journal, 96(3), 19-25. https://doi.org/10.2307/30047289

Johnson, A. P. (2005). A Short Guide to Action Research. Boston: Pearson Education.

Johnson, A. P. (2014). Eylem araştırması el kitabı (Çev. Ed. Yıldız Uzuner ve Meltem Özten Anay). Ankara: Anı Yayıncilık.

Kalaycı, N. T. (2015). Toplumsal cinsiyet eşitliği açısından bir çizgi film çözümlemesi: Pepee. Eğitim Ve Bilim, 40(177), 243-270.

Karabay, A. (2014). Dinleme Metinlerinin Sınıf İçi Uygulamaları. Hacettepe Üniversitesi Eğitim Fakültesi Dergisi (H. U. Journal of Education), 29(3), 81-94.

Karakaş, A., \& ve Sarıçoban, A. (2011). Altyazılı çizgi filmlerin öğrencilerin tesadüfî kelime öğrenimleri üzerine etkileri. 20. Ulusal Eğitim Bilimleri Kurultayı Bildirisi. Burdur: Mehmet Akif Ersoy Üniversitesi Eğitim Fakültesi.

Karakuş, N., \& ve Baki, Y. (2015). Keloğlan Çizgi Filminin Kalıplaşmış Dil Birimleri Yönünden Değerlendirilmesi. International Journal of Languages' Education and Teaching, 2038-2056.

Karatay, H. (2007). Kelime Öğretimi. (Turkish). Gazi University Journal of Gazi Educational Faculty (GUJGEF), (1), 141-153.

Kelly, L. L. (2013). Hip-Hop Literature: The Politics, Poetics, and Power of Hip-Hop in the English Classroom. English Journal, 102(5), 51-56.

Kersulov, M. L. (2016). Emotional truth with fictional images: Reading and writing nonfiction comics in the secondary classroom. English Journal, 105(4), 69-75. Retrieved from http://search.proquest.com/docview/1774318995?accountid=15572

Kılıçkaya, F., \& Krajka, J. (2012). Can the use of web-based comic strip creation tool facilitate EFL learners' grammar and sentence writing? British Journal of Educational Technology, 43(6), 161-165. https://doi.org/10.1111/j.1467-8535.2012.01298.x

Koh, A. (2015) Popular Culture goes to school in Hong Kong: a Language Arts curriculum on revolutionary road? Oxford Review of Education, 41(6), 691-710. https://doi.org/10.1080/03054985.2015.1110130

Korean Ministery of Education. (2015). Retrieved from http://english.moe.go.kr/enMain.do

Kuzu, A. (2009). Öğretmen Yetiştirme ve Mesleki Gelişimde Eylem Aratırması. Uluslararası Sosyal Aratırmalar Dergisi, 2(6), 425-433.

Lawrence, S. A., McNeal, K., \& Yildiz, M. N. (2009). Summer Program Helps Adolescents Merge Technology, Popular Culture, Reading, and Writing for Academic Purposes. Journal of Adolescent \& Adult Literacy, 52(6), 483-494. https://doi.org/10.1598/JAAL.52.6.3

Love, B. L. (2014). Urban storytelling: how storyboarding, moviemaking, and hip-hop-based education can promote students' critical voice. English Journal, (5), 53.

Marsh, J. (2006). Popular Culture in the Literacy Curriculum: A Bourdieuan Analysis. Reading Research Quarterly, 41(2), 160-174. https://doi.org/10.1598/RRQ.41.2.1

Marsh, J., \& Millard, E. (2000). Literacy and Popular Culture. Using children's culture in the classroom. London: Paul Chapman.

Marsh, J., Brooks, G., Hughes, J., Ritchie, L., Roberts, S., \& Wright, K. (2005). digital beginnings: young children's use of popular culture, media and new technologies. Sheffield: University of Sheffield. 
Marshall, J., \& Klein, A. M. (2009). Lessons in Social Action: Equipping and Inspiring Students to Improve Their World. Social Studies, 100(5), 218-221. https://doi.org/10.1080/00377990903221962

McCrary, D. (2005). Represent, Representin, Representation: The Efficacy of Hybrid Texts in the Writing Classroom. Journal of Basic Writing, 24(2), 72-91.

McLaren, P. (2011). Okullarda yaşam, eleştirel pedagojiye giriş (Çev. Ed. Mustafa Yunus Eryaman ve Hasan Arslan). Ankara: Anı Yayınc1lik.

MEB. (2006). İlköğretim 6-8. Sinıf Türkçe Öğretim Programı. Talim Terbiye Kurulu: Ankara.

MEB. (2013). PISA 2012 ulusal ön raporu. Ankara. Retrieved from http://pisa.meb.gov.tr/wp-content/uploads/2013/12/pisa2012-ulusal-on-raporu.pdf adresinden alınmıştır

MEB. (2015). İlköğretim 1-8. Sinıf Türkçe Dersi Öğretim Programı (Taslak). Talim Terbiye Kurulu: Ankara.

Mei-Hung, W., \& Boe-Shong, H. (2012). Words and Worlds in Pictures: Comic Teaching in Stephen Crane's "The Open Boat". International Journal of Learning, 18(7), 165-185.

Miles M., \& Huberman, M. (1994). An expanded sourcebook qualitative data analysis (2nd ed.). CA: Sage Publications.

Mills, G. E. (2003). Action Research: A guide for the teacher researcher (2. bsk.). New Jersey: Merrill Prentice Hall.

Ministry of Education and Research. (2015). Retrieved from http://www.government.se/

Moje, E. B., \& Sutherland, L. M. (2003). The Future of Middle School Literacy Education. English Education, 35(2), 149-164.

Morrell, E., \& Duncan- Andreda, J. (2006). Popular culture and critical media pedagogy in secondary literacy. International Journal of Learning, 12, 1-12.

Müller-Hartmann, A. (2007). Is Disney Safe for Kids?-Subtexts in Walt Disney's Animated Films. Amerikastudien / American Studies, (3), 399.

Oktay, A. (2010). 21. yüzyılda yeni eğilimler ve eğitim (2. Bsk.). Orhan Oğuz, Ayla Oktay, Halis Ayhan (Yayıma Hazırlayanlar). 21. Yüzyılda Eğitim ve Türk Eğitim Sitemi (1-21) içinde. Ankara: Pegem Akademi.

Ornstein, A. C., \& ve Hunkins, P. F. (2014). Program Alanı (çev. Sadife Demiral). Eğitim Programı, Temeller, İlkeler ve Sorunlar (Cev. Ed. Asım Arı) icinde (1-43). Konya: Eğitim Yayınevi.

Otmazgin, N., \& Project, M. (2014). Regionalizing culture: The political economy of Japanese popular culture in Asia. Honolulu: University of Hawaii Press.

Patton, M. Q. (2014). Nitel Araştırma ve Değerlendirme Yöntemleri (çev. Mesut Bütün ve Selçuk Beşir Demir). Ankara: Pegem Akademi.

Pelton, R. P. (2010). Action research for teacher candidates: using classroom data to enhance instruction $/$ edited by Robert P. Pelton; foreword by Richard Sagor. Lanham, Md.: Rowman \& Littlefield Education.

Petracca, M., \& Sorapure, M. (1998). Common culture: Reading and writing about American popular culture (2nd ed.). Upper Saddle River: Prentice Hall.

Pixton. (2015). Retrieved from https://www.pixton.com/tr/

Rapp, D. N. (2011). Comic books' latest plot twist: Enhancing literacy instruction. Phi Delta Kappan, 93(4), 64-67. https://doi.org/10.1177/003172171109300416

Rickford, J. R., \& Finegan, E. (2004). Language in the U.S.A: Themes for the 21st Century. New York: Cambridge University Press.

Rosenblatt, L. (1982). The Literary Transaction: Evocation and Response. Theory into Practice, 21, 268-277. https://doi.org/10.1080/00405848209543018

Rosenblatt, L. M. (1988). Writing and reading: The Transactional Theory (Technical Report No. 416). Cambridge: University of Illinois.

Schoen, S. F., \& Nolen, J. (2004). Action research: Decreasing acting-out behavior and increasing learning. Teaching Exceptional Children, 37(1), 26-29. https://doi.org/10.1177/004005990403700103 
Schoon Tanis, K. A. (2010). “Wait. I can use that in my classroom?”: Popular culture in/and secondary english language arts (Order No. 3435243). ProQuest Dissertations \& Theses Global. (816097756). Retrieved from http://search.proquest.com/ adresinden

Schultz, K., \& Throop, R. (2012). Popular Culture. In P. Peterson, E. Baker, \& B. McGaw (Eds.), International Encyclopedia of Education, 1, 318-323. Oxford: Elsevier.

Schwarz, G. (2006). Expanding Literacies through Graphic Novels. English Journal, 95(6), 58-64. https://doi.org/10.2307/30046629

Sever, S. (2006). Türkçe Öğretiminin Çözülemeyen Sorunları. Varlık Dergisi, (1189), 8-16.

Sever, S. (2011). Türkçe öğretimi ve tam öğrenme. Ankara: Anı Yayıncılık.

Sitomer, L. (2006). Tupac Shakur in Language Arts class? Instructor, 116(2), 66-67.

Skinner, E. N. (2006). Teenage addiction: Adolescent girls drawing upon popular culture texts as mentors for writing in an after-school writing club (Order No. 3225198). ProQuest Dissertations \& Theses Global. (305362210). Retrieved from http://search.proquest.com/

Stevens, L. P. (2001). "South Park" and Society: Instructional and Curricular Implications of Popular Culture in the Classroom. Journal of Adolescent \& Adult Literacy, 44(6), 548-555.

Sünger Bob: Büyükannenin Öpücüğ̈̈. (2001). Retrieved from http://www.cizgifilm.in/

The Ontorio Curriculum Gardes 1-8. (2009). Retrieved from http://www.edu.gov.on.ca/eng/

Türkmen, N. (2012). Çizgi Filmlerin Kültür Aktarımındaki Rolü Ve Pepee. Sosyal Bilimler Dergisi/Journal of Social Sciences, 36(2), 139-158.

Uçgun, D. (2014). Tarihi süreç içerisinde Türkçe Öğretim Programlart ve Türkçe öğretmenlerinin yetiştirilmesi (2. Bsk.). In A. Güzel \& ve H. Karatay (Eds.), Türkçe Öğretimi El Kitabı (pp. 89-107) içinde. Ankara: Pegem Akademi.

Uzuner, Y. (2005). Baş Makale: Özel Eğitimden Örneklerle Eylem Araştırmaları. Ankara Üniversitesi Eğitim Bilimleri Fakültesi. Özel Ĕ̆itim Dergisi, 6(2), 1-12.

Vcasmo. (2015). Retrieved from http://www.vcasmo.com/

Willett, R. (2005). Baddies in the classroom: media education and narrative writing. Literacy, 39(3), 142-148. https://doi.org/10.1111/j.1467-9345.2005.00412.x

Wissman, K. K., \& Costello, S. (2014). Creating Digital Comics in Response to Literature: Aesthetics, Aesthetic Transactions, and Meaning Making. Language Arts, 92(2), 103-117.

Yaylagül, L., \& ve Korkmaz, N. (2008). Medya, Popüler Kültür ve İdeoloji. Ankara: Dipnot Yayınları.

Yıldırım, A., \& ve Şimşek, H. (2013). Sosyal Bilimlerde Nitel Araştırma Yöntemleri (9. bsk.). Ankara: Seçkin Yayincilik.

Zeichner, K. M. (2009). Teacher education and the struggle for social justice / Kenneth M. Zeichner. New York: Routledge.

Zimmerman, B. (2008). Creating Comics Fosters Reading, Writing, and Creativity. Education Digest, 74(4), 55-57.

\section{Copyrights}

Copyright for this article is retained by the author(s), with first publication rights granted to the journal.

This is an open-access article distributed under the terms and conditions of the Creative Commons Attribution license (http://creativecommons.org/licenses/by/4.0/). 